\title{
Srovnání ekonomiky běhu na základě př́ijmu kyslíku u vytrvalostních běžců na asfaltu, škváře a tartanu
}

\author{
The Comparison of Running Economy by 0xygen Uptake \\ in Long Distance Runners on Asphalt, Cinder and Tartan
}

\author{
Jaroslava Chovancová, Martina Bernaciková, Jan Novotný, Tomáš Kalina, Miriam Kalichová
}

Fakulta sportovních studií, Masarykova univerzita, Brno

\begin{abstract}
Abstrakt
Cílem této studie bylo porovnat ekonomiku běhu (pomocí príimu kyslíku) u vytrvalostních běžců na třech různých površích (asfalt, škvára a tartan). Na studii se podilelo třicet českých vytrvalců

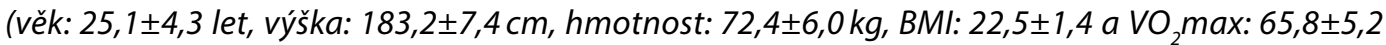
$\left.\mathrm{ml} \cdot \mathrm{min} \cdot \mathrm{kg}^{-1}\right)$. Příjem kyslíku jsme měřili bezdrátovým analyzátorem vzduchu Oxygen Mobile (Viasys) na každém povrchu u následujících rychlostí: 10, 12, 14 a $16 \mathrm{~km} \cdot \mathrm{h}^{-1}$. Rozdily př́jmu kyslíku byly hodnoceny za použití parametrické analýzy rozptylu (ANOVA) opakovaných měřeních a následného post- hoc Tukeyho HSD testu. Našli jsme signifikantní rozdily mezi asfaltem a škvárou u 12, 14 a16 $\mathrm{km} \cdot h^{-1}$. A dále mezi tartanem a škvárou při rychlosti $12 \mathrm{~km} \cdot h^{-1}$. Na tartanu byly zaznamenány hodnoty príjmu kyslíku při rychlosti $10 \mathrm{~km} \cdot \mathrm{h}^{-1}: 35,2 \pm 2,8 \mathrm{ml} \cdot \mathrm{min} \cdot \mathrm{kg}^{-1} ; 12 \mathrm{~km} \cdot \mathrm{h}^{-1}: 41,0 \pm 3,4 \mathrm{ml} \cdot \mathrm{min} \cdot \mathrm{kg}^{-1}$; $14 \mathrm{~km} \cdot h^{1}: 47,8 \pm 4,2 \mathrm{ml} \cdot \mathrm{min} \cdot \mathrm{kg}^{-1}$ a $16 \mathrm{~km} \cdot \mathrm{h}^{-1}: 54,2 \pm 4,9 \mathrm{ml} \cdot \mathrm{min} \cdot \mathrm{kg}^{-1}$; na škváre při rychlosti $10 \mathrm{~km} \cdot \mathrm{h}^{-1}$ : $36,2 \pm 3,6 \mathrm{ml} \cdot \mathrm{min} \cdot \mathrm{kg}^{-1} ; 12 \mathrm{~km} \cdot \mathrm{h}^{-1}: 42,5 \pm 3,9 \mathrm{ml} \cdot \mathrm{min} \cdot \mathrm{kg}^{-1} ; 14 \mathrm{~km} \cdot \mathrm{h}^{-1}: 49,5 \pm 5,4 \mathrm{ml} \cdot \mathrm{min} \cdot \mathrm{kg}{ }^{-1}$ a $16 \mathrm{~km} \cdot \mathrm{h}^{-1}:$ $56,1 \pm 6,8 \mathrm{ml} \cdot \mathrm{min} \cdot \mathrm{kg}^{-1}$ a na asfaltu pri rychlosti $10 \mathrm{~km} \cdot \mathrm{h}^{-1}: 35,0 \pm 3,7 \mathrm{ml} \cdot \mathrm{min} \cdot \mathrm{kg}^{-1} ; 12 \mathrm{~km} \cdot \mathrm{h}^{-1}: 39,8 \pm 4,0$ $\mathrm{ml} \cdot \mathrm{min} \cdot \mathrm{kg}{ }^{-1} ; 14 \mathrm{~km} \cdot h^{-1}: 46,3 \pm 5,1 \mathrm{ml} \cdot \mathrm{min} \cdot \mathrm{kg}^{-1}$ a $16 \mathrm{~km} \cdot h^{-1}: 53,5 \pm 4,8 \mathrm{ml} \cdot \mathrm{min} \cdot \mathrm{kg}^{-1}$. Nejnižší hodnoty př́ijmu kyslíku byly zaznamenány na asfaltu. Asfalt je pravděpodobně nejvýhodnější povrch z pohledu príjmu kyslíku, resp. energetické náročnosti pro běžce.
\end{abstract}

\begin{abstract}
The purpose of this study was to compare running economy (by oxygen consumption) in long distance runners on three different surfaces (asphalt, cinder and tartan). Thirty Czech long distance runners (age: $25.1 \pm 4.3$ years, height: $183.2 \pm 7.4 \mathrm{~cm}$, body mass: $72.4 \pm 6.0 \mathrm{~kg}, \mathrm{BMl}: 22.5 \pm 1.4$ and $\mathrm{VO}_{2}$ max: $\left.65.8 \pm 5.2 \mathrm{ml} \cdot \mathrm{min} \cdot \mathrm{kg}^{-1}\right)$ participated in this study. We measured oxygen uptake by wireless, portable cardiopulmonary stress testing system (Oxygen Mobile, Viasys) on each surface during running at speeds: $10,12,14$ and $16 \mathrm{~km} \cdot \mathrm{h}^{-1}$. Differences of oxygen uptake were assessed statistically using parametric ANOVA and post-hoc Tukey HSD test. We found significant differences between asphalt and cinder for 12,14 and $16 \mathrm{~km} \cdot h^{-1}$. Differences of average values of oxygen uptake on tartan at $10 \mathrm{~km} \cdot \mathrm{h}^{-1}: 35.2 \pm 2.8$ $\mathrm{ml} \cdot \mathrm{min} \cdot \mathrm{kg}^{-1} ; 12 \mathrm{~km} \cdot \mathrm{h}^{-1}: 41.0 \pm 3.4 \mathrm{ml} \cdot \mathrm{min} \cdot \mathrm{kg}^{-1} ; 14 \mathrm{~km} \cdot \mathrm{h}^{-1}: 47.8 \pm 4.2 \mathrm{ml} \cdot \mathrm{min} \cdot \mathrm{kg}^{-1} \mathrm{a} 16 \mathrm{~km} \cdot \mathrm{h}^{-1}: 54.2 \pm 4.9$ $\mathrm{ml} \cdot \mathrm{min} \cdot \mathrm{kg}^{-1}$; on cinder at $10 \mathrm{~km} \cdot \mathrm{h}^{-1}: 36.2 \pm 3.6 \mathrm{ml} \cdot \mathrm{min} \cdot \mathrm{kg}^{-1} ; 12 \mathrm{~km} \cdot \mathrm{h}^{-1}: 42.5 \pm 3.9 \mathrm{ml} \cdot \mathrm{min} \cdot \mathrm{kg}{ }^{-1} ; 14 \mathrm{~km} \cdot \mathrm{h}^{-1}$ : $49.5 \pm 5.4 \mathrm{ml} \cdot \mathrm{min} \cdot \mathrm{kg}^{-1}$ a $16 \mathrm{~km} \cdot \mathrm{h}^{-1}: 56.1 \pm 6.8 \mathrm{ml} \cdot \mathrm{min} \cdot \mathrm{kg}^{-1}$ and on asphalt at $10 \mathrm{~km} \cdot \mathrm{h}^{-1}: 35.0 \pm 3.7 \mathrm{ml} \cdot \mathrm{min} \cdot-$ $\mathrm{kg}^{-1} ; 12 \mathrm{~km} \cdot \mathrm{h}^{-1}: 39.8 \pm 4.0 \mathrm{ml} \cdot \mathrm{min} \cdot \mathrm{kg}^{-1} ; 14 \mathrm{~km} \cdot \mathrm{h}^{-1}: 46.3 \pm 5.1 \mathrm{ml} \cdot \mathrm{min} \cdot \mathrm{kg}^{-1}$ a $16 \mathrm{~km} \cdot \mathrm{h}^{-1}: 53.5 \pm 4.8 \mathrm{ml} \cdot \mathrm{min} \cdot \mathrm{kg}^{-1}$. The lowest values of oxygen uptake were found on asphalt surface. The asphalt is probably the most favorable surface according to energetic aspect.
\end{abstract}

Klíčová slova: ekonomika běhu, vytrvalostní běh, príjem kyslíku, běžecké povrchy, oxycon mobile

Keywords: running economy, long distance running, oxygen uptake, running surfaces, oxycon mobile 


\section{Úvod}

Vytrvalost je chápána jako komplex předpokladů dlouhodobě vykonávat pohybovou činnost požadovanou intenzitou bez snížení její efektivity za určitý časový úsek (Jančík 2007, Grasgruber, Cacek 2009).

V naší studii jsme se zaměřili na běžce, kteří rozvíjí stř̌ednědobou a dlouhodobou vytrvalost. U dlouhodobé vytrvalosti je dominantním způsobem energetického krytí aerobní způsob úhrady energie s využitím glykogenu a později i tuků. Energetickým zdrojem střednědobé vytrvalosti je glykogen. Dle Jančíka a kol. (2006) jsou nejvyšší aerobní možnosti organismu kombinovány s aktivací anaerobního systému získávání energie právě při stř̌ednědobé vytrvalosti.

Aerobní výkon je podmiňován širokým spektrem faktorů, přičemž mezi nejcitovanější řadí odborníci maximální př́jem kyslíku ( $\left.\mathrm{VO}_{2} \max \right)$, úroveň anaerobního prahu (\% z VO $2 \mathrm{max}$ ) a ekonomiku běhu (Bassett, Howley 2000, Grasgruber, Cacek 2009, Jones 2007). Ekonomika běhu neboli energetická náročnost představuje podle výsledků řady vědeckých studií (Berg 2003, Jones 2007, Midgley 2007, Petersen et al. 2007, Saunders et al. 2004) jeden z nejdůležitějších faktorů, které podmiňuji úroveň vytrvalostních výkonů. Bez dobré ekonomiky běhu není možné podávat kvalitní běžecké výkony.

Běžecká ekonomika je vyjádřena požadovanou spotřebou $\mathrm{kyslíku} \mathrm{v} \mathrm{ml} \cdot \mathrm{kg}^{-1}$ tělesné hmotnosti za minutu nutnou k pohybové aktivitě vytrvalostního charakteru při zvolené rychlosti. Je výsledkem spolupůsobení mnoha různých faktorů, mezi které můžeme nejčastěji zahrnout fyziologické faktory (\% $\mathrm{VO}_{2} \max$ při konkrétní rychlosti, distribuce svalových vláken, laktát), somatické faktory (tělesná hmotnost a výška, délka lýtka, šířka boků, poloha a stabilita boků, procento tělesného tuku, index trupu, distribuce svalové hmoty na nohou, index tělesné hmotnosti), exogenní vlivy (odpor vzduchu, hmotnost obuvi, typ oděvu, nadmořská výška) a techniku běhu (délka kroku, odrazová síla, úhlová rychlost plantární flexe, oscilace těžiště, flexibilita, délka tréninku v letech), (Anderson 1996, Kyröläinen 2001, Noakes 2003, Grasgruber, Cacek 2009).

Příjem kyslíku je přímo úměrný se stoupající rychlosti běhu, proto se s narůstající rychlostí př́ijem kyslíku zvyšuje. Méně ekonomický běžec musí při konkrétní rychlosti spotřebovávat větší množství kyslíku, takže na úrovni $\mathrm{VO}_{2}$ max dosáhne nižší rychlosti běhu nežli vysoce ekonomický běžec, přestože hodnoty $\mathrm{VO}_{2}$ max mohou být u obou stejné. Za výbornou hodnotu energetické náročnosti běhu při rychlosti $16 \mathrm{~km} \cdot \mathrm{h}^{-1}$ a sklonu běhátka $1 \%$ se ukázala hodnota $44-47 \mathrm{ml} \cdot \mathrm{kg}^{-1} \cdot \mathrm{min}^{-1}$, dle př́jmu kyslíku v přepočtu na $1 \mathrm{~km} \cdot \mathrm{h}^{-1}$ rychlosti běhu a sklonu běhátka $1 \% 170-179 \mathrm{ml} \cdot \mathrm{kg}^{-1} \cdot \mathrm{km}^{-1}$ (Novotný 2011, Jones 2007).

Velkou roli zastává v energetické náročnosti i běžecká obuv. Myers a Steudel (1985) uvádí, že se kvưli těžké běžecké obuvi ( $1,8 \mathrm{~kg})$, zhoršuje až o $24,3 \%$ a tím snižuje mechanickou efektivitu běhu.

Problematikou běžecké ekonomiky se zabývala celá řada renomovaných odborníků, kteří např. porovnávali ekonomiku u různých výkonnostních skupin, osob rozdílného pohlaví či u běhu provozovaného při určité rychlosti na rovině nebo do kopce (Beneke 2005, Noakes 2003, Mercer 2008). V námi dostupné literatuře jsme se nesetkali s komparací běžecké ekonomiky provozované na typických běžeckých površích tratě, jako je tartan, asfalt a škvára, propojených se změnou rychlosti běhu.

Cílem práce bylo zjistit rozdíly energetické náročnosti vytrvalostního běhu na různých površích tratě, při různých rychlostech běhu u skupiny běžců výkonnostní až vrcholové úrovně. Zajímá nás, který typ povrchu bude pro běžce nejméně energeticky náročný. Bude ekonomika běhu nejvýhodnější na tartanu a nejméně výhodná na škváře?

Znalost energetické náročnosti může být $\mathrm{v}$ praxi použitelná př̀i plánování efektivnějšího tréninku. Tato studie by nám mohla pomoci s doporučením, který typ běžeckého podkladu zvolit při tréninku, aby byl běžec adaptován např. na těžší podmínky. Díky tréninku v těchto podmínkách by mohl být závodník schopen dosáhnout lepšího výkonu. 


\section{Metodika}

\section{Charakteristika souboru}

Výzkumný soubor tvoří třicet trénovaných mužů specializujících se na vytrvalostní běh. Závodnímu běhu se věnovali déle než tři roky. V daném testovacím období byli zdraví, aktivně se připravovali na nejbližší závodní sezonu s tréninkovými dávkami alespoň 4 krát týdně, nebyli zranění. Všichni byli na výkonnostní nebo vrcholové úrovni v České republice, účastnili se běhů na dráze, silnici $(\mathrm{N}=18)$ nebo orientačního běhu $(\mathrm{N}=12)$. Jejich závodními disciplínami byly běh na $1500 \mathrm{~m}, 5000 \mathrm{~m}, 10000 \mathrm{~m}$ a půlmaratón. Orientační běžci závodili v kategoriích sprint, middle a long, které se liší délkou závodu a technickou náročností. V tabulce 1 uvádíme charakteristiku souboru.

Tab. 1 Charakteristika výzkumného souboru.

\begin{tabular}{|l|l|}
\hline Počet & 30 \\
\hline Věk (roky) & $25,1 \pm 4,30$ \\
\hline Tělesná hmotnost $(\mathrm{kg})$ & $72,4 \pm 5,95$ \\
\hline Tělesná výška $(\mathrm{cm})$ & $183,2 \pm 7,44$ \\
\hline Index tělesné hmotnosti (BMI) & $21,5 \pm 1,39$ \\
\hline $\mathrm{VO}_{2} \max \left(\mathrm{ml} \cdot \mathrm{kg}^{-1} \cdot \mathrm{min}^{-1}\right)$ & $65,8 \pm 5,15$ \\
\hline ANP $\left(\% \mathrm{VO}_{2} \max \right)$ & $80 \pm 0,06$ \\
\hline
\end{tabular}

(Data jsou uvedena v podobě průměru a směrodatné odchylky.)

Výzkumný soubor tvořili běžci působící v Brně a okolí. Výkonnost oslovených jsme sledovali z výsledků aktuálních závodů daného období (Mistrovství ČR v silničním běhu mužů, žen, juniorů a juniorek - do 10 místa, „Vokolo príglu“ - do 30 místa, Brněnský běžecký pohár - do 25 místa, kola I. a II. národní ligy družstev - do 6 místa). Po oslovení jsme s každým rozebírali běžecké plány, abychom si byli jisti, že budou splňovat všechny naše podmínky z hlediska fyzického i organizačního. Nejdůležitější podmínkou z hlediska výkonnosti bylo, aby úroveň ANP (anaerobního prahu) každého běžce byla nad rychlostí běhu $16 \mathrm{~km} \cdot \mathrm{h}^{-1}$. Běžce, u kterých jsme si tímto nebyli jisti, jsme testovali vstupním laboratorním testem na běhátku do submaximálního výkonu. Test byl totožný jako test to maxima (viz níže), jen s tím rozdílem, že byl ukončen do 2 min po dosažení ANP. S běžci, kteří dosáhli do rychlosti $16 \mathrm{~km} \cdot \mathrm{h}^{-1}$ ANP, jsme spolupráci ukončili.

Vytrvalce, u kterých jsme si byli jisti vhodností výkonnosti pro náš výzkum, jsme netestovali. Toto rozhodnutí jsme vyvodili kvůli aktuální výkonnosti v daném testovacím období z výsledků Z velkých běžeckých závodů, kde se umístovali na předních prríčkách závodu (Mistrovství České republiky na dráze a orientačním běhu - do 5 místa, RunTOUR - do 5 místa, Mistrovství České republiky v silničním běhu - do 20 místa).

Ukazatelem ekonomické náročnosti jsme stanovili $\mathrm{VO}_{2} \cdot \mathrm{kg}^{-1}\left(\mathrm{ml} \cdot \mathrm{min} \cdot \mathrm{kg}^{-1}\right)$ nezávislou proměnnou byly tři běžecké povrchy: asfalt, tartan a škvára a čtyři rychlosti $10,12,14 \mathrm{a} 16 \mathrm{~km} \cdot \mathrm{h}^{-1}$.

Měřní se uskutečnilo na podzim 2012 a jaře 2013. V průběhu jednoho kalendářního měsíce běžci absolvovali jeden laboratorní test do maximálního výkonu a tři testy na běžeckých oválech. Testovaní jedinci absolvovali všechny testy v odpočatém stavu, ne po náročném tréninku či závodě. V den testování absolvovali trénink až po našem testování.

Všichni testovaní běželi ve stejném typu obuvi, pro každého běžce jsme měli nový pár. Byla vybrána běžecká závodní obuv značky Gel_Hyperspeed 5 (Asics, Japan). Hmotnost 221 g ve velikosti UK 8 se sníženým odtlumením (Němec, 2012).

Důvodem pro použití stejné běžecké obuvi bylo vyloučení jednoho z exogenních vlivů. Rozdílný 
typ obuvi, opotřebení a hmotnost by mohlo celou studii ovlivnit. Běžci používali obuv pouze na dané testování, včetně rozklusání a vyklusání.

\section{Laboratorni testy}

Test do maximálního výkonu se uskutečnil v laboratoři sportovní medicíny na Fakultě sportovních studií v Brně. Testování bylo provedeno na běhátku s $1 \%$ náklonem, po individuální př́pravě běžce na výkon (rozklusání, rozcvičení). Počátek testu začínal na rychlosti běhu $10 \mathrm{~km} \cdot \mathrm{h}^{-1}$ $\mathrm{s}$ lineárním stupňováním, kde každou minutu následovala vyšší rychlost $\mathrm{o} 1 \mathrm{~km} \cdot \mathrm{h}^{-1}$, do maxima. Andrew, Jonathan (1996) uvádí, že 1\% náklon běhátka zvyšuje energetickou náročnost a tím kompenzuje absenci odporu vzduchu testů v laboratoři. Při 1\% náklonu tedy dochází ke srovnání výdeje energie mezi testy $\mathrm{v}$ terénu a $\mathrm{v}$ laboratoři.

\section{Terénni testy}

Terénní testy probíhaly na brněnských sportovištích škol (základních, středních a vysokých) vždy za standardních podmínek z hlediska počasí (bez extrémních teplot, větru, deště). Pro hodnocení ekonomiky běhu jsme použili modifikovaný Saltinův submaximální test (1995). Před začátkem samotného testu došlo $\mathrm{k}$ prrípravné fázi (dle individuálních potřeb). Při samotném testu běžci absolvovali čtyři čtyřminutové úseky při rychlostech: $10,12,14$ a $16 \mathrm{~km} \cdot \mathrm{h}^{-1}$ vždy se čtyřminutovou pauzou mezi jednotlivými úseky. V průběhu jednoho úseku běželi konstantní rychlostí. Pro udržení správné rychlosti sloužili 3 pomůcky: kužely po $100 \mathrm{~m}$, zvuk píštalky a konkrétní znalost mezičasu.

\section{Použité prístroje}

- Oxycon Mobile (Jaeger, USA) - analyzátor dechových plynů. Přesnost po kalibraci $\mathrm{VO}_{2}$ je udávána výrobcem na $50 \mathrm{ml} \cdot \mathrm{min}^{-1}$,

- Katana 40 (Lode, Nizozemí) - běžecký pás, použitá rychlost 10 až $23 \mathrm{~km} \cdot \mathrm{h}^{-1}$, náklon $1 \%$, délka $220 \mathrm{~cm}$, šírka $70 \mathrm{~cm}$,

- S 610i (Polar, Finland) - měřič tepové frekvence, použito při všech testech,

- BC 543 (Tanita, USA) - osobní digitální váha, měřeno s přesností $0,1 \mathrm{~kg}$.

\section{Statistické zhodnocení naměrených dat}

Analýza hodnot absolutní spotřeby kyslíku a relativní spotřeby vztažené k tělesné hmotnosti proběhla na exportních datech z Oxycon Mobile, která byla průměrována na 15 sekundovém intervalu v posledních 2 minutách zátěže dané rychlosti. Jako průměrnou hodnotu jsme použili aritmetický průměr hodnot, které se nacházejí ve druhém a třetím kvartilu. Hodnoty $\mathrm{z}$ oblasti $\mathrm{Q}_{1}$ a $\mathrm{Q}_{4}$ jsme do našeho měření nezahrnuli $\mathrm{z}$ důvodu utlumení externích hodnot.

Pro vyhodnocení rozdílů metabolicko-energetických ukazatelů jsme využili statistické vyhodnocení, parametrickou analýzu rozptylu (ANOVA) opakovaných měření (provedeno pro každou rychlost samostatně), Tukey HSD test, kde faktory je povrch a rychlost běžeckého pohybu a závislou proměnnou $\mathrm{VO}_{2} \cdot \mathrm{kg}^{-1}$. Hladina významnosti byla stanovena pro hodnoty $\mathrm{p} \leq 0,05$.

\section{Výsledky}

Na obr. č. 1 a tab. č. 2 můžeme vidět výsledky jedné ze sledovaných proměnných - př́ijmu kyslíku. Při $10 \mathrm{~km} \cdot \mathrm{h}^{-1}$ nebyl zaznamenán statisticky významný rozdíl mezi žádným ze sledovaných povrchů. U vyšších rychlostí, tedy 12,14 a $16 \mathrm{~km} \cdot \mathrm{h}^{-1}$, jsme statisticky významný rozdíl zaznamenali mezi povrchy asfalt a škvára. Při rychlosti $12 \mathrm{~km} \cdot \mathrm{h}^{-1}$ se objevil i statisticky významný rozdíl mezi tartanem a škvárou. Data při rychlosti $16 \mathrm{~km} \cdot \mathrm{h}^{-1}$ byla zpracována z 29 výsledků sledovaných běžců. Důvodem vyloučení jednoho testovaného bylo nesplnění námi stanovené výkonnostní podmínky (na jednom z povrchů jeho ANP nepřesáhl $16 \mathrm{~km} \cdot \mathrm{h}^{-1}$ ). $\mathrm{VO}_{2} \cdot \mathrm{kg}^{-1} \mathrm{se}$ s narůstající rychlostí zvýšil. 
Ve všech rychlostech byl nejvyšší př́ijem kyslíku na škváře. Při nejnižší rychlosti se příjem kyslíku na asfaltu a tartanu nelišil, v ostatních rychlostech byl $\mathrm{VO}_{2} \cdot \mathrm{kg}^{-1}$ vyšší na tartanu než asfaltu.

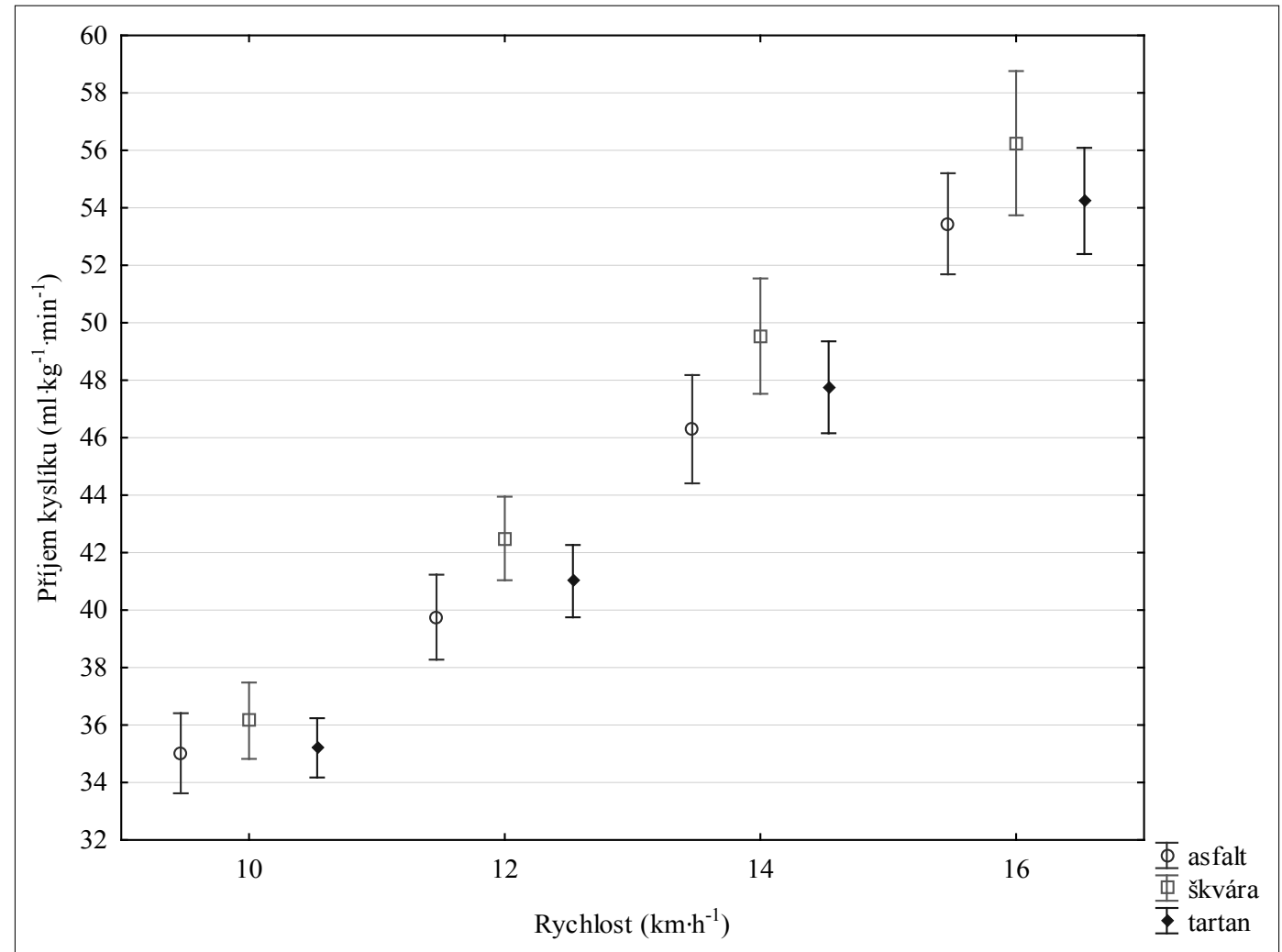

(data jsou uvedena v podobě průměru a $95 \%$ intervalu spolehlivosti)

Obr. 1 Výsledky př́ijmu kyslíku na kilogram hmotnosti běžce.

Tab. 2 Výsledky analýzy rozptylu př́ijmu kyslíku.

\begin{tabular}{|c|c|c|c|c|c|c|}
\hline \multirow{2}{*}{ Rychlost } & \multirow{2}{*}{ Povrch } & \multirow{2}{*}{$\begin{array}{c}\dot{\mathrm{VO}} \mathrm{O}_{2} \cdot \mathrm{kg}^{-1} \\
\left(\mathrm{ml} \cdot \mathrm{kg}^{-1} \cdot \mathrm{min}^{-1}\right)^{*}\end{array}$} & \multicolumn{2}{|c|}{ ANOVA } & \multirow{2}{*}{\multicolumn{2}{|c|}{$\begin{array}{l}\text { POST- HOC test } \\
\text { Tukey HSD test }\end{array}$}} \\
\hline & & & $\mathrm{F}$ & $\mathrm{p}$ & & \\
\hline \multirow{3}{*}{$10 \mathrm{~km} \cdot \mathrm{h}^{-1}$} & Asfalt & $35,0 \pm 3,73$ & \multirow{3}{*}{2,706} & \multirow{3}{*}{0,075} & \multicolumn{2}{|c|}{-} \\
\hline & Škvára & $36,2 \pm 3,56$ & & & \multicolumn{2}{|c|}{-} \\
\hline & Tartan & $35,2 \pm 2,76$ & & & \multicolumn{2}{|c|}{-} \\
\hline \multirow{3}{*}{$12 \mathrm{~km} \cdot \mathrm{h}^{-1}$} & Asfalt & $39,8 \pm 3,96$ & \multirow{3}{*}{10,725} & \multirow{3}{*}{0,000} & $A-\check{S}$ & $\mathrm{p}=0,000$ \\
\hline & Škvára & $42,5 \pm 3,89$ & & & $T-\check{S}$ & $p=0,039$ \\
\hline & Tartan & $41,0 \pm 3,37$ & & & $A-T$ & $p>0,05$ \\
\hline \multirow{3}{*}{$14 \mathrm{~km} \cdot \mathrm{h}^{-1}$} & Asfalt & $46,3 \pm 5,05$ & \multirow{3}{*}{6,975} & \multirow{3}{*}{0,001} & $A-\check{S}$ & $p=0,001$ \\
\hline & Škvára & $49,5 \pm 5,38$ & & & $T-\check{S}$ & $p>0,05$ \\
\hline & Tartan & $47,8 \pm 4,23$ & & & $A-T$ & $p>0,05$ \\
\hline \multirow{3}{*}{$\begin{array}{c}16 \mathrm{~km} \cdot \mathrm{h}^{-1} \\
* *\end{array}$} & Asfalt & $53,5 \pm 4,78$ & \multirow{3}{*}{3,584} & \multirow{3}{*}{0,034} & $\mathrm{~A}-\check{\mathrm{S}}$ & $p=0,031$ \\
\hline & Škvára & $56,1 \pm 6,78$ & & & $T-\check{S}$ & $p>0,05$ \\
\hline & Tartan & $54,2 \pm 4,89$ & & & $A-T$ & $p>0,05$ \\
\hline
\end{tabular}

Legenda: * jedná se o průměr a směrodatnou odchylku, ** N=29, A - asfalt, $\check{\mathrm{S}}-{ }^{*}$ škvára, T - tartan 


\section{Diskuse}

Z naměřených dat vyplývá, že nejvíce náročným povrchem $\mathrm{z}$ hlediska $\mathrm{VO}_{2} \cdot \mathrm{kg}^{-1}$ je škvára a nejméně náročným asfalt. Při běhu na škváře dochází $\mathrm{k}$ nejvyšší energetické náročnosti. Běžcem vykonaná práce se $\mathrm{v}$ největší míře mění na vnitřní energii a to především $\mathrm{z}$ důvodu nedostatečně velké třecí síly mezi částicemi podložky. Škvára tak nevytváŕí dostatečně pevný podklad pro vykonání odrazu. Na tartanu jsme zaznamenali nižší energetickou náročnost než na škváře. Přeměny mechanické energie na vnitřní jsou na tartanu minimální, dochází k pružné deformaci podložky, z níž se energie přeměňuje zpět na kinetickou energii běžce. U asfaltu jsme zaznamenali nejlepší hodnoty pro námi sledované závislé proměnné. Přestože se nejedná o pružný povrch jako je tartan, na základě impulsu síly se domníváme, že je to právě pevnost a tvrdost povrchu, co sportovci při správné technice běhu umožňuje vytvořit maximální sílu reakce podložky, která následně zrychluje jeho pohyb.

Sassi et al. (2011) naměřil u fotbalistů př́jem kyslíku při běhu na asfaltu při rychlosti $10 \mathrm{~km} \cdot \mathrm{h}^{-1}: 35,6 \mathrm{ml} \cdot \mathrm{min} \cdot \mathrm{kg}^{-1}$ a $12 \mathrm{~km} \cdot \mathrm{h}^{-1}: 43,4 \mathrm{ml} \cdot \mathrm{min} \cdot \mathrm{kg}^{-1}$. My jsme naměřili $35,0 \mathrm{ml} \cdot \mathrm{min} \cdot \mathrm{kg}^{-1}$ a $39,8 \mathrm{ml} \cdot \mathrm{min} \cdot \mathrm{kg}^{-1} \mathrm{u}$ vytrvalostních běžců při stejných rychlostech. Naše hodnoty jsou nižší než hodnoty publikované Sassi et al. (2011), zvláště při rychlosti $12 \mathrm{~km} \cdot \mathrm{h}^{-1}$. Sassi et al. (2011) porovnával ekonomiku běhu mezi asfaltem a trávou. Ve svém příspěvku publikuje hodnoty příjmu kyslíku u fotbalistů na trávě při rychlosti $10 \mathrm{~km} \cdot \mathrm{h}^{-1}: 37,7 \mathrm{ml} \cdot \mathrm{min} \cdot \mathrm{kg}^{-1}$ a $12 \mathrm{~km} \cdot \mathrm{h}^{-1}: 46,2 \mathrm{ml} \cdot \mathrm{min} \cdot \mathrm{kg}^{-1}$.

V naší předchozí studii (Novotná et al., 2008) jsme měřili ekonomiku běhu u vytrvalostních běžců na tartanu. Podobné hodnoty příjmu kyslíku jsme naměřili při rychlostech 12,14 a 16 $\mathrm{km} \cdot \mathrm{h}^{-1}\left(35,8 \mathrm{ml} \cdot \mathrm{min} \cdot \mathrm{kg}^{-1} ; 40,8 \mathrm{ml} \cdot \mathrm{min} \cdot \mathrm{kg}^{-1}\right.$ a $\left.46,0 \mathrm{ml} \cdot \mathrm{min} \cdot \mathrm{kg}^{-1}\right)$ u maratonců. U běžců, specializujících se na střední tratě, jsme při stejných rychlostech zaznamenali hodnoty př́imu kyslíku 38,1 $\mathrm{ml} \cdot \mathrm{min} \cdot \mathrm{kg}^{-1} ; 44,1 \mathrm{ml} \cdot \mathrm{min} \cdot \mathrm{kg}^{-1}$ a $49,4 \mathrm{ml} \cdot \mathrm{min} \cdot \mathrm{kg}^{-1}$.

\section{Závěry}

Cílem naši práce bylo zjistit rozdíly v energetické náročnosti vytrvalostního běhu na různých površích tratě, při různých rychlostech běhu u třiceti běžců výkonnostní až vrcholové úrovně.

$\mathrm{Z}$ našich výsledků můžeme konstatovat, že statisticky významné rozdíly metabolicko-energetických ukazatelů ekonomiky běhu jsme nalezli u $\mathrm{VO}_{2} \cdot \mathrm{kg}^{-1}$ mezi povrchy: asfalt - škvára, škvára - tartan na $12 \mathrm{~km} \cdot \mathrm{h}^{-1}$. Nejméně ekonomicky náročným povrchem se ukázal asfalt, nejvíce škvára.

Prvotní předpoklad, že tartan bude nejméně náročným podkladem pro běžecký výkon, se nepotvrdil. Je nejpoužívanějším typem povrchu v závodních podmínkách, kde se zdolávají světové rekordy, proto jsme očekávali, že zde bude energetická náročnost nejnižší.

Do budoucna navrhujeme sledovat parametry ekonomiky běhu na dalších površích jako je např. tráva čí písek a u různých skupin probandů (běžci, fotbalisti, nesportovci). Následně tyto výsledky porovnat $\mathrm{s}$ výsledky $\mathrm{z}$ měření na tartanu a asfaltu.

Tato studie byla financována ze Specifického výzkumného projektu Masarykovy univerzity MUNI/A/0802/2012.

\section{Literatura}

Anderson, T., (1996). Biomechanics and running economy. Sports. Med., 22, 76-89.

Bassett, D. R., \& Howley, E. T. (2000). Limiting factors for maximum oxygen uptake and determinants of endurance performance. Medicine and science in sports and exercise, 1, 70-84.

Beneke, R., \& Hütler, M. (2005). The effect of training on running economy and performance in recreational athletes. Medicine and science in sports and exercise, 10, 1794-1799.

Berg, K. (2003). Endurance training and performance in runners: research limitations and unanswered questions. Sports medicine (Auckland, N.Z.), 1, 59-73. 
Grasgruber, P., \& Cacek, J. (2008). Sportovní geny. (Vyd. 1., 480 s.) Brno: Computer Press.

Havlíčková a kol., (2006). Fyziologie tělesné zátěže l, obecná část. (Vyd. 2., 203 s.) Univerzita Karlova v Praze: Karolinum.

Jančík, J., Závodná E. \& Novotná M., (2007). Fyziologie tělesné zátěže. (Elportál) Brno: Masarykova univerzita. Dostupné z WWW http://is.muni.cz/do/1499/el/estud/fsps/js07/fyzio/texty/index.html.

Jones, A. M. (2007) Middle-and long-distance running. In: Sport and Exercise Physiology Testing Guidelines. Vol. I - Sport Testing.Winter EM et al. (eds.). Routledge (147-154 p.) New York.

Jones, A. M., \& Doust, J. H. (1996). A 1\% treadmill grade most accurately reflects the energetic cost of outdoor running. Journal of sports sciences, 4, 321-327.

Kyröläinen, H., Belli, A., \& Komi, P. V. (2001). Biomechanical factors affecting running economy. Medicine and science in sports and exercise, 8, 1330-1337.

Kuhn, K. (2005). Vytrvalostní trénink. České Budějovice: KOOP.

Kučera, V. \& Truksa, Z. (2000). Běhy na střední a dlouhé tratě. Praha: Olympia.

Máček, M. \& Radvanský, J. (2011). Fyziologie a klinické aspekty pohybové aktivity. Praha: Galén.

Mercer, J et al. (2008). The physiological importance of prefered stride frequency during at different speeds. J Exerc Physiol, 11, 26-32.

Midgley, A. W., McNaughton, L. R., \& Jones, A. M. (2007). Training to enhance the physiological determinants of long-distance running performance: can valid recommendations be given to runners and coaches based on current scientific knowledge? Sports medicine (Auckland, N.Z.), 10, 857-880.

Myers, M. J., \& Steudel, K. (1985). Effect of limb mass and its distribution on the energetic cost of running. The Journal of experimental biology, 363-373.

Němec, O., Asics Gel-Hyperspeed 5, Retrieved from http://o.nemoc.cz/zbozi/3878/ASICS-GEL-HYPERSEED-5----barva.8501htm.

Noakes, T., (2003). Lore of running. 4th ed. Champaign, III. (931 p.) Human Kinetics.

Novotná, M. \& Novotný, J. (2007). Fyziologická podstata rychlostního a vytrvalostního běžeckého výkonu. (Vyd. 1, 60 s.) Brno: Masarykova univerzita.

Novotná, M., (2008). Ekonomika běhu a aerobní kapacita u středotrat’ařu a maratonců. In Šimek, D., Cacek, J. \& Novotný, J. Sport a kvalita života 2008. (101-105 s.) Brno: Masarykova univerzita, Fakulta sportovních studií.

Novotna, M., Simek, D., Cacek, J. \& Novotny, J. (2008). Running economy and aerobic capacity in distance and marathon runners. In 17th Annual Meeting of European Society of Movement Analysis for Adults and Children. Turkey.

Novotná, M., Novotný J. \& Sebera M., (2007). Modifikovaný Saltinův test v terénních podmínkách pro hodnocení běžecké ekonomiky a aerobní kapacity. In Sport a kvalita života. (6 s.) Brno: Fakulta sportovních studií MU.

Novotný, J., Sebera, M., Hrazdira, L., Novotná, M. \& Chaloupecká, A., (2006). Kapitoly sportovní medicíny. Elportál, Brno: Masarykova univerzita. Dostupné z WWW https://is.muni.cz/do/rect/el/estud/fsps/ps06/sportmed/web/index1.html.

Petersen, K., Hansen, C. B., Aagaard, P., \& Madsen, K. (2007). Muscle mechanical characteristics in fatigue and recovery from a marathon race in highly trained runners. European journal of applied physiology, 3, 385-396.

Sassi, A., Stefanescu, A., Menaspa', P., Bosio, A., Riggio, M., \& Rampinini, E. (2011). The cost of running on natural grass and artificial turf surfaces. Journal of strength and conditioning research / National Strength \& Conditioning Association, 3, 606-611.

Saunders, P. U., Pyne, D. B., Telford, R. D., \& Hawley, J. A. (2004). Factors affecting running economy in trained distance runners. Sports medicine (Auckland, N.Z.), 7, 465-485.

Saltin, B., Kim, C. K., Terrados, N., Larsen, H., Svedenhag, J., \& Rolf, C. J. (1995). Morphology, enzyme activities and buffer capacity in leg muscles of Kenyan and Scandinavian runners. Scandinavian journal of medicine \& science in sports, 4, 222-230.

Šimek, D. (2008). Analýza fyziologických ukazatelů běžců vytrvalců. Diplomová práce. Brno: Masarykova univerzita, Fakulta sportovních studií.

Zahradník, D. \& Korvas, P., (2012). Základy sportovního tréninku. Fakulta sportovních studií, Brno: MU. Dostupné z WWW http://www.fsps.muni.cz/ tvodicka/data/reader/book-5/Impresum.html. 